ZOOLOGIA 27 (6): 986-992, December, 2010

doi: $10.1590 /$ S1984-46702010000600022

\title{
External morphology of Cotesia flavipes (Hymenoptera: Braconidae) during larval development
}

\author{
Daniela O. Pinheiro'; Guilherme D. Rossi' \& Fernando L. Cônsoli', 2
}

\author{
${ }^{1}$ Laboratório de Interações em Insetos, Departamento de Entomologia e Acarologia, USP/ESALQ. Avenida Pádua Dias 11, \\ 13418-900 Piracicaba, SP, Brazil.E-mail: daniela_pinheiro@yahoo.com \\ 2 Corresponding author. E-mail: fconsoli@esalq.usp.br
}

\begin{abstract}
Cotesia flavipes (Cameron, 1891) (Hymenoptera) is a gregarious endoparasitoid used in applied biological control against Diatraea saccharalis (Fabricius, 1794) (Lepidoptera). In this study, we characterize the larval external morphology and the number of instars of $C$. flavipes. Parasitized larvae of $D$. saccharalis were sampled from the $1^{\text {st }}$ to the $10^{\text {th }}$ day after parasitism and dissected in an anticoagulant buffer for collection of $C$. flavipes immatures. Immatures were processed for scanning electron microscopy. Larvae of $\mathrm{C}$. flavipes were prepared in $\mathrm{NaOH}$ solution and slide mounted to allow for mandible size measurements. Analysis of measurements of the parasitoid larval mandible size indicated that $C$. flavipes has three instars. Newly hatched larvae are caudate-mandibulate, assuming a hymenopteriform shape later in their development. The anal vesicle began to expand in the first instar and, once expanded, remained unchanged up to the beginning of the third instar. At the third instar, the anal vesicle decreased in volume. Herein we report the development and possible functions of the larval external structures modified during the development of $C$. flavipes, as for example their role in aiding newly-eclosed larvae to avoid the host immune response and to move within the host. To summarize the morphological changes during parasitoid growth, we should mention that the modifications in the anal vesicle were correlated with the feeding activity, and the maintenance of the anal vesicle indicates that this structure remained functional, probably playing a role in nutrient absorption and host regulation. On the other hand, the mandibles of early stage larvae are probably used to assist the parasitoid larvae during eclosion.
\end{abstract}

KEY WORDS. Anal vesicle; biological control; functional morphology; ultrastructure.

Immature parasitoids develop in only one host, from which they obtain their nutritional requirements and, in some cases, the physical support to develop (DeBACH \& Rosen 1991, GRENIER 1997). Parasitized hosts will usually die after parasitoid egression or become sterile. In either case, parasitized hosts are unable to transfer their genes to the next generation (VINSON 1997). Parasitoids are well adapted to exploit their hosts at several life stages and under a diversity of habitats, making them suitable candidates for use in pest control. Cotesia flavipes (Cameron, 1891) is one example of a natural enemy that is used in extensive areas in many Brazilian states to control the most common pest of sugarcane, the sugarcane borer Diatraea saccharalis (Fabricius, 1794) (Lepidoptera: Crambidae) (BотеLно \& MACEDO 2002).

Females of $C$. flavipes oviposit directly into the host haemocoel, and the number of eggs will depend on the host age (BREWER \& KING 1981). This parasitoid remains within the host during its whole embryonic and larval development, being both dependent on the temperature conditions and development status of the host (PÁdua et al. 1994). Parasitoids will egress from the body cavity of the host to pupate after producing a characteristic silk cocoon (for review see BotelHo \& MacEDo 2002).
Most morphological descriptions of braconids are based on adults, with little attention paid to the immatures. Although general descriptions of the external morphology are available for several braconids (HAGEN 1964, Finlayson 1987, FisCher et al. $2006,2008)$, there is no detailed description of the morphology of the immature of $C$. flavipes throughout its development.

Koinobionts induce a series of changes in the physiology of their hosts to guarantee successful colonization and development. Most of these changes are synchronized with the development of the immature parasitoid, as they are induced to alter the internal environment of the host to attend the requirements of the specific stage of the parasitoid development. We are conducting a series of studies on the mechanisms used by $C$. flavipes to regulate their host physiology, and evaluating metabolites, hormonal, and molecular changes in several host tissues throughout parasitoid development. To correctly correlate the functional changes observed in the host due to parasitoid development, it is necessary to determine and characterize the immature development of C. flavipes. Therefore, we characterize the number of instars and the external morphological characteristics of $C$. flavipes by scanning electron microscopy. 


\section{MATERIAL AND METHODS}

Larvae of $D$. saccharalis were reared on an artificial diet based on soybean meal and wheat germ (PARRA \& Minsfeldt 1992), under controlled conditions $\left(26 \pm 1^{\circ} \mathrm{C} ; 60 \pm 10 \% \mathrm{RH} ; 14\right.$ h photophase), following PARRA (1999). Adults of $C$. flavipes were fed with a $10 \%$ honey solution (v/v) and kept inside plastic Petri dishes (65 x $22 \mathrm{~mm})$.

Last instars of $D$. saccharalis at the head capsule slippage stage were subjected to parasitization by $C$. flavipes. A single oviposition was allowed. Parasitized larvae were kept at controlled conditions and only larvae moulting to the last instar within 12 hours after parasitization were further used in the experiments. Parasitized larvae were kept in plastic Petri dishes (90 x $14 \mathrm{~mm}$ ) containing artificial diet and were sampled daily until parasitoid egression. Host larvae were dissected in an anticoagulant buffer (98 mM NaOH, $0.19 \mathrm{M} \mathrm{NaCl}, 1.7 \mathrm{mM}$ EDTA, $41 \mathrm{mM}$ citric acid, pH 4.5) (STRAND et al. 1997), and immature parasitoids were collected for further analysis.

Larvae of C. flavipes were collected daily from at least five parasitized hosts and pooled in groups of one-hundred larvae, carefully washed three times in the anticoagulant buffer, and immersed in $1 \% \mathrm{NaOH}$ solution $(\mathrm{w} / \mathrm{v})$. The time of exposure to the $\mathrm{NaOH}$ solution varied according to the status of larval development. Older larvae remained in the solution for a longer period of time in order to have tissues properly cleared. Larvae were then mounted in slides and observed under inverted light microscope (MOTIC AE 31); the length of one of the mandibles was measured with the help of the image analysis software Motic Images Advanced 3.2. The number of instars was determined by the frequency distribution of the mandible sizes in accordance with the Dyar's rules (PARRA \& HADDAD 1989).

External larval morphology was investigated under scanning electron microscopy (Digital Scanning Microscope DSM 940 A - Zeiss). Larvae were fixed in $2.5 \%$ glutaraldehyde in 100 $\mathrm{mM}$ cacodylate buffer, $\mathrm{pH} 7.2$ for $24 \mathrm{~h}$, and post-fixed in $1 \%$ osmium tetroxide for $1 \mathrm{~h}$ in the same buffer. Samples were dehydrated in a graded series of ethanol and finally dried under liquid $\mathrm{CO}_{2}$ (CPD 030; Balzer Union). Specimens were mounted on adequate supports and sputter-coated with a $20 \mathrm{~nm}$ layer of gold in the apparatus BALTEC (Sputter Coater - SCD 050).

The terminology used in the description of the immature stages of $C$. flavipes followed that of HaGEN (1964) and FisCHER et al. (2008).

\section{RESULTS AND DISCUSSION}

Larvae of $C$. flavipes were not observed in parasitized $D$. saccharalis up to the third day after parasitism, indicating that this parasitoid has an embryonic development that lasts almost $1 / 4$ of its entire preimaginal development. The frequency distribution of the lengths of individual mandibles showed that larvae of $C$. flavipes molted twice (Tab. I). In our samples, $C$. flavipes larvae eclosed between days three and four after parasitization, as observed for several other endoparasitoids (Egulleor et al. 2001, Luo et al. 2007, Yu et al. 2008). Daily larval mandible measurements showed that the first molt occurred between the $5^{\text {th }}$ and $6^{\text {th }}$ day after oviposition, while the second molt was observed between the $7^{\text {th }}$ and $8^{\text {th }}$ day (Tab. I). The differences in the size of the mandibles of $C$. flavipes were within the growth rate expected by the Dyar's rule, allowing the characterization of all three instars of this parasitoid (PARRA \& HADDAD 1989).

Table I. Mandible length, growth ratio and days of development after oviposition of $C$. flavipes.

\begin{tabular}{cccc}
\hline Instar & $\begin{array}{c}\text { Mandible length } \\
(\mu \mathrm{m})\end{array}$ & Growth ratio & $\begin{array}{c}\text { Days after } \\
\text { oviposition }\end{array}$ \\
\hline $1^{\text {st }}$ & $41.15 \pm 8.87$ & - & $3-5$ \\
$2^{\text {nd }}$ & $57.75 \pm 11.18$ & 1.40 & $6-7$ \\
$3^{\text {rd }}$ & $82.60 \pm 23.48$ & 1.43 & $8-10$
\end{tabular}

Note: data of length of mandible indicates mean \pm SD.

All instars of $C$. flavipes larvae exhibited similar external features (Figs 1-12) with the exception of the enlargement of the anal vesicle and the loss of the dorsal spines as larvae aged. Besides these two structures, no other morphological structure was noticed on the body surface of the larvae of $C$. flavipes we studied. Young larvae have thin, 15 to $20 \mu \mathrm{m}$ long spines (Figs 1-3) located at the middle of the dorsal plate of the abdominal segments. These structures were observed only in first instars, and no differences in their morphology could be observed along the body surface. It is very likely that these structures aid parasitoid larvae to move within the host, allowing their distribution within the body of the host, as parasitoid eggs will basically concentrate around the intense tracheoles arising from the tracheal trunks nearby the last pair of spiracles ("tokus lung") (FLC, personal observation). It has been recently suggested that parasitoid eggs may rest on these tracheal tufts to acquire the required oxygen supply to sustain their embryonic development (RAo et al. 2009). Therefore, the spines at the body surface could aid $C$. flavipes larvae to craw their way out of the tracheal tufts of the eightieth abdominal segment into the hemocoel of the host, avoiding larval competition and concentration at the same feeding site.

It is also possible to detect an invagination at the central region of the body of C. flavipes larvae (Fig. 2), which has also been observed in other hymenopterans. Endoparasitic Hymenoptera larvae may also show external traits that represent adaptations to the environments they exploit, and both structures observed on the body surface of $C$. flavipes larvae can be adaptive responses to the parasitoid requirements for locomotion, protection, ingestion and respiration during host exploitation (DєBАсн 1968). 


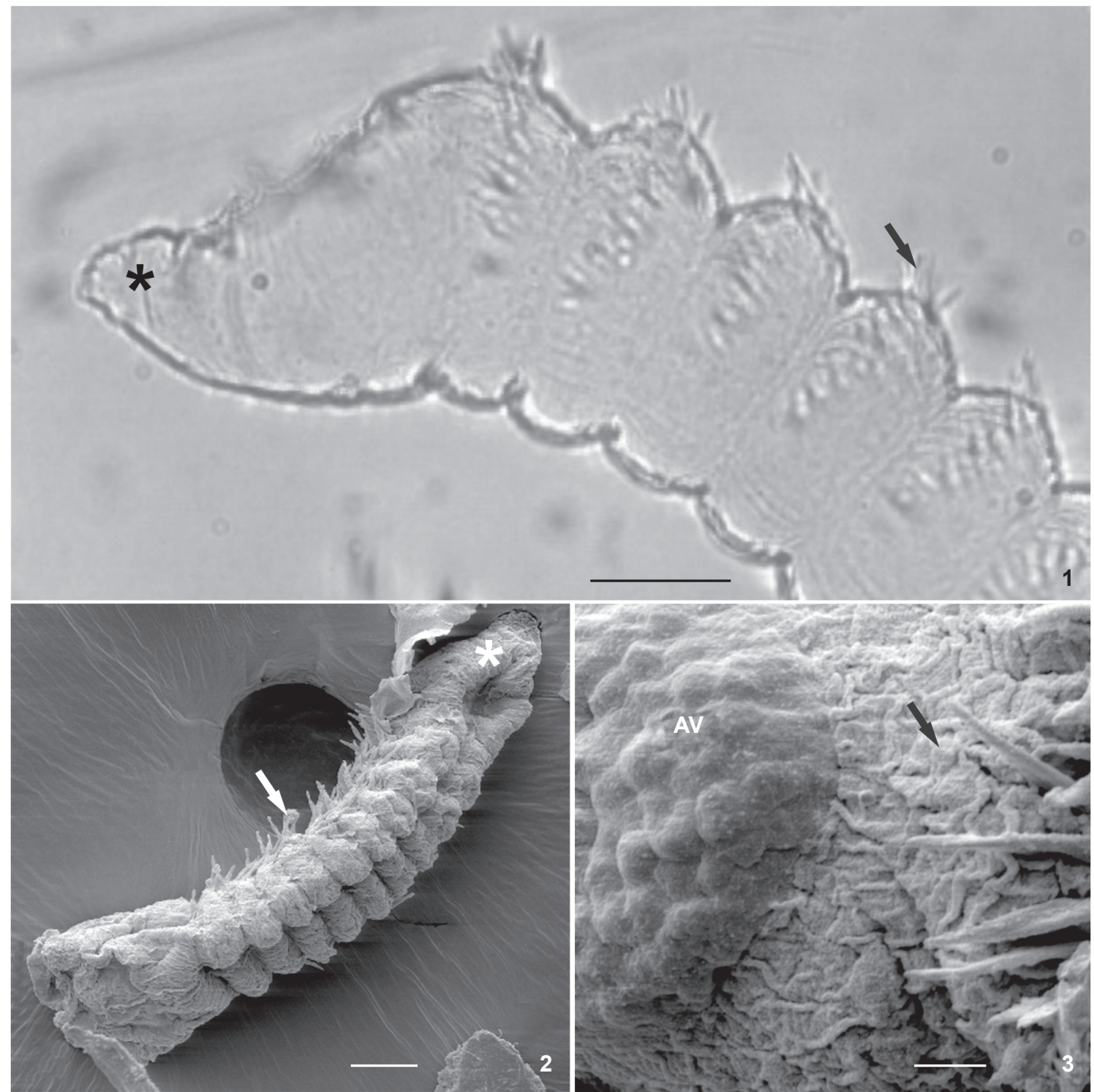

Figures 1-3. (1) Cotesia flavipes larva after $\mathrm{NaOH}$ treatment. Posterior region of caudate-mandibulate ( $\star$ ) larvae, note the spines (arrow), four days after oviposition; bar $=10 \mu \mathrm{m}$. (2) General view of a C. flavipes larva still attached to chorion remnants. Cuticular spines are indicated by an arrow. Note invagination of the median longitudinal line; bar $=54 \mu \mathrm{m}$. (3) Detail of posterior region indicating the beginning of anal vesicle (AV) formation. Note the small, round to oval projections in the anal vesicle three days after oviposition; the spines are thin and elongated (arrow); bar $=10 \mu \mathrm{m}$.

First instars eclosed as caudate-mandibulate (Figs 1 and 2 ), but they soon assumed the hymenopteriform shape. The size of the caudae of caudate-mandibulate larvae is reduced to a vestigial v-like structure that develops into the anal vesicle (Figs 4 and 5), as observed in other parasitic hymenopterans (Rosa et al. 1990, Xu et al. 2007, FIscher et al. 2008), and is thought to favor parasitoid development as an adaptation to the internal environment of the host (KaEsLin et al. 2006).
The anal vesicle appeared as an evagination of the posterior gut formed by a group of round and small projections (Fig. $3)$. The development of the anal vesicle of $C$. flavipes was very similar to that of C. vestalis (Haliday, 1834) (Yu et al. 2008), but quite different from Chelonus inanitus (Linnaeus, 1767) (Braconidae) (KAEsLin et al. 2006).

The anal vesicle of $C$. flavipes enlarged rapidly during the first days of development (Figs 8 and 10), regressing in size 


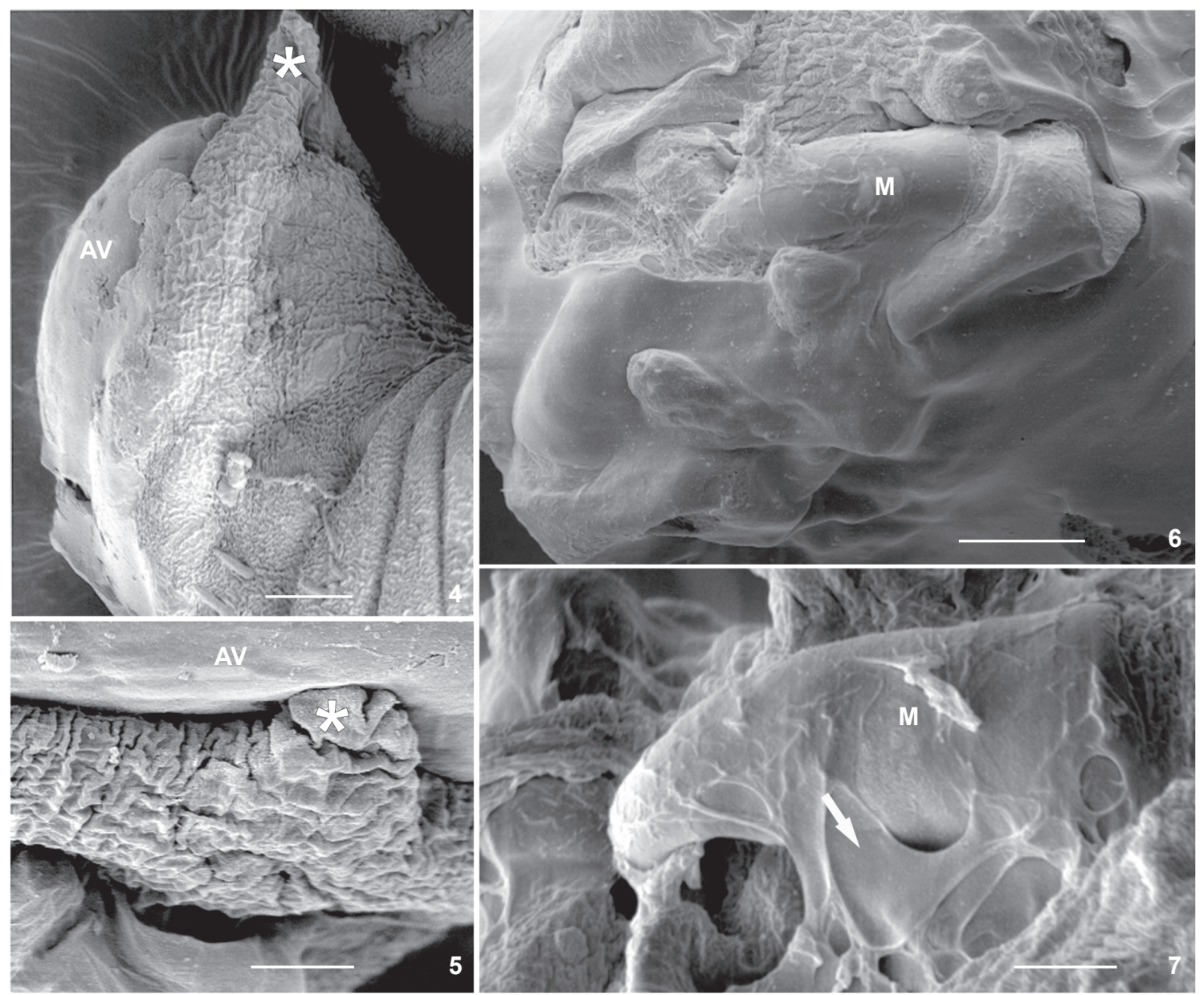

Figures 4-7. (4) General view of the ventral region of a C. flavipes larva. Note the short v-shaped caudal projection at the anal region ( $\star$ ), close to the anal vesicle (AV); bar $=40 \mu \mathrm{m}$. (5) Detail of the v-shaped caudal projection ( $*$ ); note the irregular membrane and anal vesicle (AV) four days after oviposition; bar $=20 \mu \mathrm{m}$. (6) The oral region with a mandible (M) and palps visible; bar $=20 \mu \mathrm{m}$. (7) Detail of a mandible (M) partially covered by a thin membrane (arrow) five days after oviposition; bar $=10 \mu \mathrm{m}$.

(Figs 8 and 12) later. Changes in the size of the anal vesicle have been correlated with the feeding activity of the parasitoid larvae. A reduction in the size of the anal vesicle is reported to occur in parasitoids that actively feed on host tissues at the end of their larval development, while remaining unchanged in parasitoids that do not feed directly on host tissues. The maintenance of the anal vesicle up to the end of the parasitoid larval development indicates that this structure remains functional, playing a role in nutrient absorption and host regulation (Thorpe 1932, Edson \& Vinson 1977, Kaeslin et al. 2006, Yu et al. 2008). Feeding on host tissues in Cotesia Cameron, 1891 seems to occur only after the release of enzymes, such as collagenases by the teratocytes, which will act mainly on the host fat body dissociating this tissue and making cell contents available to the developing parasitoid (NAKAMATSU et al. 2002). There are several other species that feed indirectly on host tissues after release of specific enzymes or through the action of venomassociated proteins (QIN et al. 2000, NAKAMATSU \& TANAKA 2004, GopaLapillai et al. 2005).

In the initial stages of development, the mandibles and sensorial organs were easy to observe (Figs 6 and 7). The mandibles of early stage larvae are probably used to assist the parasitoid larvae during eclosion or to prevent superparasitism (Yu et al. 2008). During larval development, a membrane-like structure covered the entire larva, and the mandibles and sensorial organs could no longer be observed (Fig. 9). The oral cavity of the larva was observed only in latter instars (Fig. 11). Although variations in the shape of the mandibles and on other head structures during larval development seems common in many other hymenopteran species (DEBACH 1968), there is no similar report of a membrane-like structure covering the mouth structures of a parasitoid larva. Parasitoid larvae are known to acquire protection 

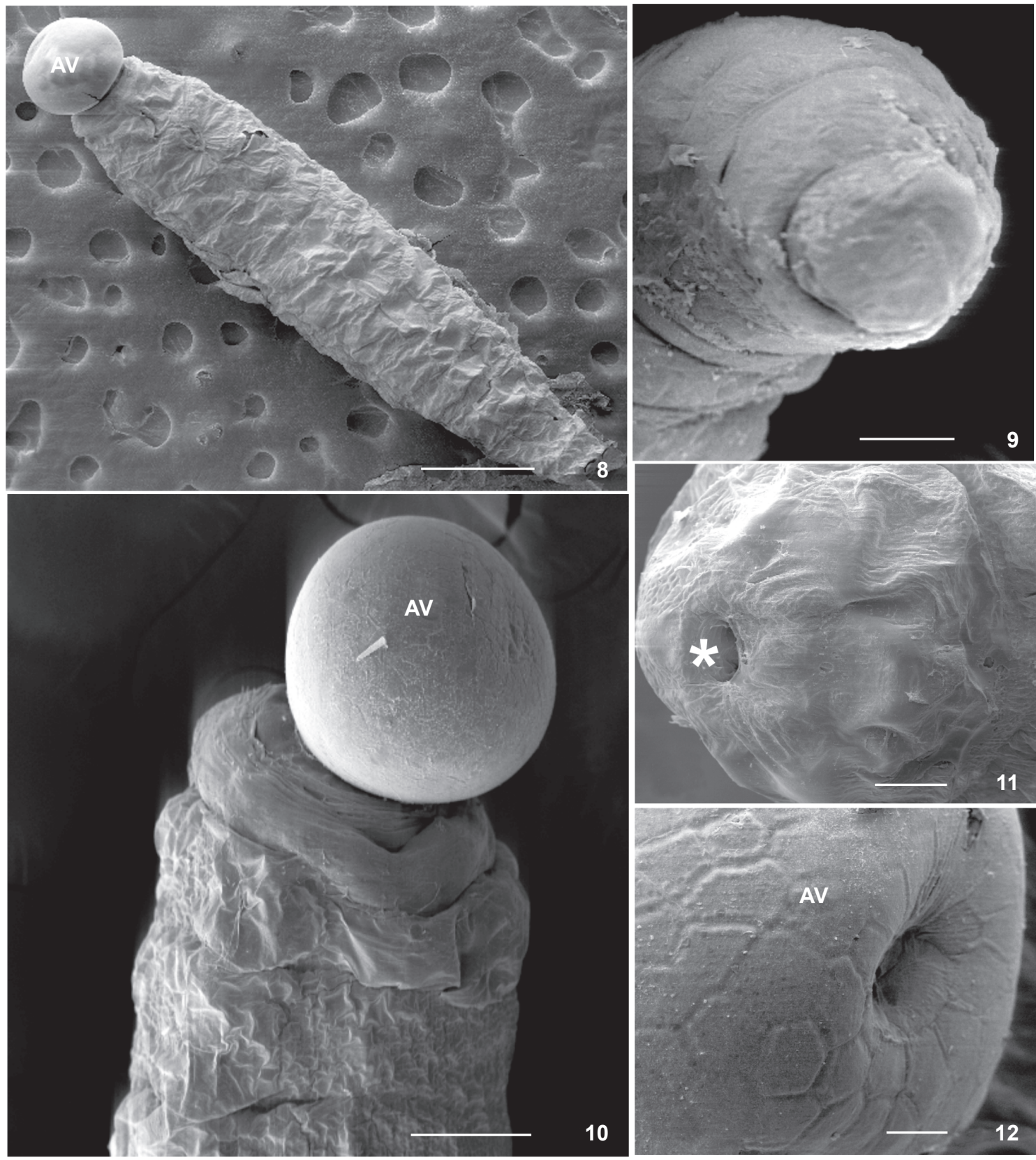

Figures 8-12. (8) General view of a C. flavipes larva with an expanded anal vesicle (AV) nine days after oviposition; bar $=583 \mu \mathrm{m}$. (9) Detail of the anterior region seven days after oviposition; bar $=174 \mu \mathrm{m}$. (10) General view of the anal region of a C. flavipes larva, with a well-developed anal vesicle (AV); bar $=200 \mu \mathrm{m}$. (11) Detail of the mouth opening ( $*$ ) at the anterior region; bar $=57 \mu \mathrm{m}$. (12) Detail of an invagination (arrow) at the posterior end of the anal vesicle (AV) nine days after oviposition; bar $=40 \mu \mathrm{m}$.

against the host immune system by remaining inside the vitellinic membrane after eclosion (CôNsoli et al. 2001) or by getting encased within a host derived sac-like structure (KaтніRIтнамвY et al. 2003). However, the layer covering the larvae of $C$. flavipes is quite different, and appears a little later during larval development.
The developmental strategies used by endoparasitic Hymenoptera have been recently reviewed, and host exploitation strategies and specific features presented by parasitoids are dependent on host phylogeny and host-parasitoid interactions (Pennacchio \& Strand 2006). Most of the adaptations parasi- 
toids have gone through are related with the regulation of the host physiology to benefit the parasitoids' own development. Many studies emphasize the diversification of developmental strategies in host-parasitoid relationships, but studies on functional morphology of the parasitoid associated structures are quite rare (for review see Pennacchio \& Strand 2006).

\section{ACKNOWLEDGMENTS}

We are grateful to the Núcleo de Apoio à Pesquisa em Microscopia Eletrônica Aplicada à Agricultura (NAP/MEPA ESALQ/USP). We also thank FAPESP for providing a research grant (05/00355-7) to FLC and fellowships to DOP (06/538307) and GDR (07/59361-1).

\section{LITERATURE CITED}

Botelho, P.S. \& N. Macedo. 2002. Cotesia flavipes para o controle de Diatraea saccharalis, p. 409-421. In: J.R.P. PARRA; P.S.M. Botelho; B.S. Corrêa-Ferreira \& J.M.S. Bento (Eds). Controle Biológico no Brasil: Parasitóides e Predadores. São Paulo, Manole, 646p.

BREwER, F.D. \& E.G. KING. 1981. Food consumption and utilization by sugarcane borers parasitized by Apanteles flavipes. Journal of Georgia Entomological Society 16: 181-185.

Cônsoli, F.L.; C.T. Wuellner; S.B. Vinson \& L.E. Gilbert. 2001. Immature development of Pseudacteon tricuspis (Diptera: Phoridae), an endoparasitoid of the red imported fire ant (Hymenoptera: Formicidae). Annals of the Entomological Society of America 94: 97-109.

DєВАсн, P. 1968. Control biologico de las plagas de insectos y malas hierbas. London, Champman and Hall, 949p.

DeBACH, P. \& D. Rosen. 1991. Biological control by natural enemies. New York, Cambridge University Press, 440p.

EDson, K.M. \& S.B. Vinson. 1977. Nutrient absorption by the anal vesicle of the braconid wasp, Microplitis croceipes. Journal of Insect Physiology 53: 5-8.

Eguileor, M.; A. Grimaldi; G. Tettamanti; R. Valssori; M.G. Leonardi; B. Giordana; E. Trembley; M.C. Digilio \& F. Pennachio. 2001. Larval anatomy and structure of absorbing epithelia in the aphid parasitoid Aphidius ervi (Haliday) (Hymenoptera: Braconidae). Arthropod Structure and Development 30: 27-37. doi: 10.1016/S1467-8039(01)00017-2.

Finlayson, T. 1987. Ichneumonoidea, p. 649-664. In: F.W. SтенR (Ed.). Immature insects. Dubuque, I.A.: Kebdall/Hunt Publishing Company, 754p.

Fischer, M.; J. Tormos; X. PARdo \& J.D. Asís. 2008. Description of adults, preimaginal phases, and the venom apparatus of a new species of Aspilota Förster from Spain (Hymenoptera: Braconidae). Zoological Studies 47: 247-257.

Fischer, M.; J. Tormos; X. Pardo; J.D. Asís; S.F. Gayubo; E. Lopes \& J. Selfa. 2006. Descriptions of adults, immature stages and the venom apparatus of two new species of Eudinostigma tobias (Hymenoptera, Braconidae), hyperparasitoids of
Phryxe caudata (Rondani) (Diptera, Tachinidae). Review of Suisse Zoology 113: 1-11.

Gopalapillai, R.; K. Kadono-Okuda \& T. OkUda. 2005. Molecular cloning and analysis of a novel teratocyte-specific carboxylesterase from the parasitic wasp, Dinocampus coccinellae. Insect Biochemistry and Molecular Biology 35: 11711180. doi:10.1016/j.ibmb.2005.05.010.

Grenier, S.A. 1997. Desenvolvimento e produção in vitro de Trichogramma, p. 235-258. In: J.R.P. PARRA \& R.A. ZUCCHI (Eds). Trichogramma e o controle biológico aplicado. Piracicaba, Fealq, 324p.

Hagen, K.S. 1964. Estados de desarrollo de los parasites, p. 205282. In: P. DEBACH (Ed.). Control biologico de las plagas de insectos y malas hierbas. London, Chapmand and Hall, 949p.

Kaeslin, M.; T. Wyler; C. GrossnikLaus-Burgin \& B. Lanzrein. 2006. Development of the anal vesicle, salivary glands and gut in the egg-larval parasitoid Chelonus inanitus: Tools to take up nutrients and to manipulate the host? Journal of Insect Physiology 52: 269-281.

Kathirithamby, J.; L.D. Ross \& J.S. Johnston. 2003. Masquerading as self? Endoparasitic Strepsiptera (Insecta) enclose themselves in host-derived epidermal bag. Proceedings of the National Academy of Sciences 100: 7655-7659. doi: 10.1073/pnas.1131999100.

Luo, K.; J. Trumble. \& Y. Pang. 2007. Development of Microplitis bicoloratus on Spodoptera litura and implications for biological control. BioControl 52: 309-321. doi: 10.1007/s10526-0069030-8.

Nakamatsu, Y. \& T. TANaKa. 2004. Venom of Euplectrus separatae causes hyperlipidemia by lysis of host fat body cells. Journal of Insect Physiology 50: 267-275. doi:10.1016/j.jinsphys. 2003.12.005.

Nakamatsu, Y.; S. Fujil \& T. Tanaka. 2002. Larvae of an endoparasitoid, Cotesia kariyai (Hymenoptera: Braconidae), feed on the host fat body directly in the second stadium with help of teratocytes. Journal of Insect Physiology 48: 1041-1052. doi: 10.1016/S0022-1910(02)00192-0.

PÁduA, L.E.M.; J.R.P. ParRa \& M.L. Haddad. 1994. Efeito da temperatura e umidade relativa do ar na biologia de Cotesia flavipes (Cameron). Anais da Sociedade Entomológica do Brasil 23: 105-114.

PARRA, J.R.P. 1999. Técnicas de criação dos insetos para programas de controle biológico. Piracicaba, Fealq, 137p.

Parra, J.R.P. \& L.H. Minsfeldt. 1992. Comparison of artificial diets for rearing the sugarcane borer, p. 195-209. In: T.E. Anderson \& N.C. Leppla (Eds). Advances in insect rearing for research and pest management. Boulder, Westview Press, 519p.

PARRA, J.R.P. \& M.L. HadDAD. 1989. Determinação do número de ínstares de insetos. Piracicaba, Fealq, 49p.

Pennacchio, F. \& M.R. STRAND. 2006. Evolution of developmental strategies in parasitic Hymenoptera. Annual Review of 
Entomology 51: 233-258. doi:10.1146/annurev.ento.51. 110104.151029.

QIN, Q.L.; H. GonG \& T. DING. 2000. Two collagenases are secreted by teratocytes from Microplitis mediator (Hymenoptera: Braconidae) cultured in vitro. Journal of Invertebrate Pathology 76: 79-80.

Rao, A.; R.E. Henderson \& S.B. Vinson. 2009. The probable significance of tracheal tufts in the $8^{\text {th }}$ abdominal segment of Helitohis virescens (F.) on the development of its parasitoid, Toxoneuron nigriceps (Viereck). Journal of Insect Physiology 55: 769-773.

Rosa, I.; B. Fernández; B. Jorge \& B. Terán. 1990. Biología de Meteorus laphygmae Viereck (Hymenoptera: Braconidae). Parte I: Fases de huevo, larva y pupa. Revista de la Facultad de Agronomía de la Universidad Central de Venezuela 16: 177-198.

Strand, M.R.; R.A. Witherell \& D. Trudeau. 1997. Two Microplitis demolitor polydnavirus mRNAs expressed in hemocytes of Pseudoplusia includens contain a common cysteine-rich domain. Journal of Virology 71: 2146-2156.

Thorpe, W.H. 1932. Experiments upon respiration in the larvae of certain parasitic hymenoptera. Proceedings of the Royal Society of London (B) 109: 450-471.

Vinson, S.B. 1997. Comportamento de seleção hospedeira de parasitóides de ovos, com ênfase na família Trichogrammatidae, p. 67-120. In: J.R.P. PARRA \& R.A. ZuCCHI (Eds). Trichogramma e o controle biológico aplicado. Piracicaba, Fealq, 324p.

Xu, P.; Z-W. WAN; X-X. Chen; S. Liu \& M-G. Feng. 2007. Immature Morphology and Development of Opius caricivorae (Hymenoptera: Braconidae), an Endoparasitoid of the Leafminer Liriomyza sativae (Diptera: Agromyzidae). Annals of the Entomological Society of America 100: 425-432.

Yu, R-X.; M. ShI; F. Huang \& X-X. Chen. 2008. Immature Development of Cotesia vestalis (Hymenoptera: Braconidae), an Endoparasitoid of Plutella xylostella (Lepidoptera: Plutellidae). Annals of the Entomological Society of America 101: 189-196.

Submitted: 04.IX.2009; Accepted: 22.V.2010.

Editorial responsibility: Gabriel L.F. Mejdalani

ZOOLOGIA 27 (6): 986-992, December, 2010 